\title{
Front Matter: Volume 10861
}

, "Front Matter: Volume 10861," Proc. SPIE 10861, Mechanisms of Photobiomodulation Therapy XIV, 1086101 (13 May 2019); doi:

$10.1117 / 12.2531285$

SPIE. Event: SPIE BiOS, 2019, San Francisco, California, United States 


\section{Mechanisms of Photobiomodulation Therapy XIV}

Michael R. Hamblin

James D. Carroll

Praveen Arany

Editors

2-3 February 2019

San Francisco, California, United States

Sponsored and Published by

SPIE 
The papers in this volume were part of the technical conference cited on the cover and title page. Papers were selected and subject to review by the editors and conference program committee. Some conference presentations may not be available for publication. Additional papers and presentation recordings may be available online in the SPIE Digital Library at SPIEDigitallibrary.org.

The papers reflect the work and thoughts of the authors and are published herein as submitted. The publisher is not responsible for the validity of the information or for any outcomes resulting from reliance thereon.

Please use the following format to cite material from these proceedings:

Author(s), "Title of Paper," in Mechanisms of Photobiomodulation Therapy XIV, edited by Michael R. Hamblin, James D. Carroll, Praveen Arany, Proceedings of SPIE Vol. 10861 (SPIE, Bellingham, WA, 2019) Seven-digit Article CID Number.

ISSN: 1605-7422

ISSN: $2410-9045$ (electronic)

ISBN: 9781510623644

ISBN: 9781510623651 (electronic)

Published by

SPIE

P.O. Box 10, Bellingham, Washington 98227-0010 USA

Telephone +1 3606763290 (Pacific Time) · Fax +1 3606471445

SPIE.org

Copyright @ 2019, Society of Photo-Optical Instrumentation Engineers.

Copying of material in this book for internal or personal use, or for the internal or personal use of specific clients, beyond the fair use provisions granted by the U.S. Copyright Law is authorized by SPIE subject to payment of copying fees. The Transactional Reporting Service base fee for this volume is $\$ 18.00$ per article (or portion thereof), which should be paid directly to the Copyright Clearance Center (CCC), 222 Rosewood Drive, Danvers, MA 01923. Payment may also be made electronically through CCC Online at copyright.com. Other copying for republication, resale, advertising or promotion, or any form of systematic or multiple reproduction of any material in this book is prohibited except with permission in writing from the publisher. The CCC fee code is 1605$7422 / 19 / \$ 18.00$.

Printed in the United States of America by Curran Associates, Inc., under license from SPIE.

Publication of record for individual papers is online in the SPIE Digital Library.

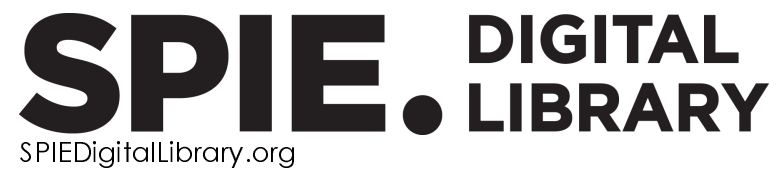

Paper Numbering: Proceedings of SPIE follow an e-First publication model. A unique citation identifier (CID) number is assigned to each article at the time of publication. Utilization of CIDs allows articles to be fully citable as soon as they are published online, and connects the same identifier to all online and print versions of the publication. SPIE uses a seven-digit CID article numbering system structured as follows:

- The first five digits correspond to the SPIE volume number.

- The last two digits indicate publication order within the volume using a Base 36 numbering system employing both numerals and letters. These two-number sets start with $00,01,02,03,04$, 05, 06, 07, 08, 09, OA, OB ... 0Z, followed by 10-1Z, 20-2Z, etc. The CID Number appears on each page of the manuscript. 


\section{Contents}

$\begin{array}{ll}\vee & \text { Authors } \\ \text { vii } & \text { Conference Committee }\end{array}$

PBM MECHANISMS II

$1086106 \quad$ Photon absorption in the mitochondria: Potential immediate and early events associated with photobiomodulation (Invited Paper) [10861-5]

$1086107 \quad$ Blue light effects in human keloid fibroblasts [10861-6]

PBM MECHANISMS III

$1086109 \quad$ Potentials of noninvasive low-level laser therapy for neonatal thrombocytopenia (Invited Paper) [10861-8]

10861 OA Reactive oxygen species explicit dosimetry to predict tumor growth for BPD-mediated vascular photodynamic therapy [10861-9]

\section{PBM INNOVATION AND COMMERCIALIZATION}

$10861 \mathrm{OB} \quad$ Fat loss by red and near infrared LED phototherapy [10861-11]

10861 OD Novel technology platform for PBM delivery using printed LEDs [10861-13]

$10861 \mathrm{OE} \quad$ Investigation of reaction mechanisms of cytochrome c and mitochondria with transient absorption spectroscopy [10861-14]

\section{NEW INVESTIGATOR}

10861 OF A fluorescence-based approach to probing the immediate/early molecular mechanisms of photobiomodulation in vitro (Invited Paper) [10861-15]

$108610 G \quad$ In vivo quantification of nitric oxide (NO) release from intact human skin following exposure to photobiomodulation wavelengths in the visible and near infrared spectrum [10861-16]

$1086101 \quad$ Measuring cytochrome c redox state using resonance Raman spectroscopy to determine metabolic rates in electron transport chain when exposed to light [10861-18] 
10861 OJ Effects of probe parameters on photobiomdulation therapy for spinal cord injury: a numerical algorithm modelling study [10861-19]

PBM CLINICAL TRANSLATION

$10861 \mathrm{OL} \quad$ Effects of high and low level 1265 nm laser irradiation on HCT116 cancer cells [10861-21]

$108610 \mathrm{~N}$ What is the prospect of transcutaneous transmission of 980 $\mathrm{nm}$ photobiomodulation therapy light to the spinal canal? [10861-23] 


\section{Authors}

Numbers in the index correspond to the last two digits of the seven-digit citation identifier (CID) article numbering system used in Proceedings of SPIE. The first five digits reflect the volume number. Base 36 numbering is employed for the last two digits and indicates the order of articles within the volume. Numbers start with $00,01,02,03,04,05,06,07,08,09,0 A, 0 B \ldots . .0 Z$, followed by 10-12, 20-2Z, etc.

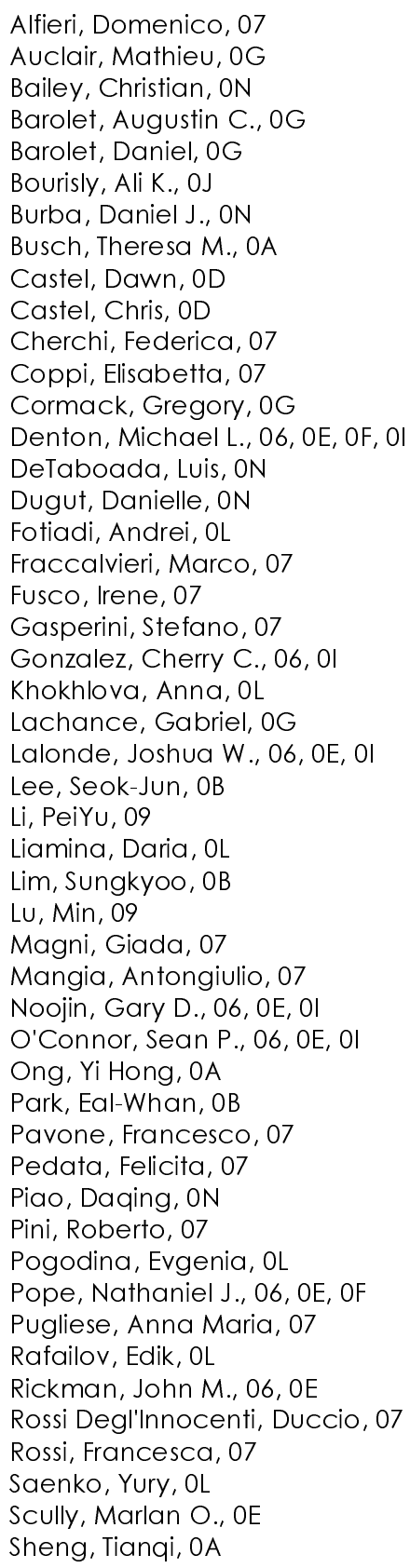

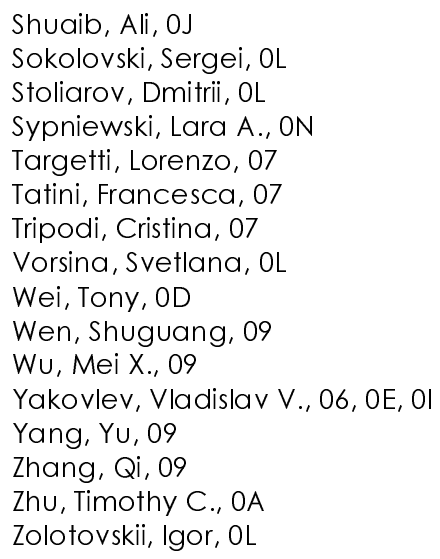


Proc. of SPIE Vol. 10861 1086101-6

Downloaded From: https://www.spiedigitallibrary.org/conference-proceedings-of-spie on 26 Apr 2023 Terms of Use: https://www.spiedigitallibrary.org/terms-of-use 


\section{Conference Committee}

Symposium Chairs

James G. Fujimoto, Massachusetts Institute of Technology (United States)

R. Rox Anderson, Wellman Center for Photomedicine, Massachusetts General Hospital (United States) and Harvard Medical School (United States)

Symposium Co-chairs

Jennifer K. Barton, The University of Arizona (United States)

Wolfgang Drexler, Medical University of Vienna (Austria)

Program Track Chairs

Brian Jet-Fei Wong, Beckman Laser Institute and Medical Clinic, University of California, Irvine (United States)

Eva Sevick, The University of Texas Health Science Center at Houston (United States)

Conference Program Committee

Heidi Abrahamse, University of Johannesburg (South Africa)

Tomas Hode, Immunophotonics, Inc. (United States)

Clark E. Tedford, LumiThera (United States)

Mei X. Wu, Harvard Medical School (United States) and Wellman

Center for Photomedicine (United States)

Session Chairs

1 PBM Mechanisms I

Michael R. Hamblin, Wellman Center for Photomedicine (United States)

2 PBM Mechanisms II

Michael L. Denton, Air Force Research Laboratory (United States)

3 PBM Mechanisms III

Mei X. Wu, Harvard Medical School (United States)

$4 \quad$ PBM Innovation and Commercialization

James D. Carroll, THOR Photomedicine Ltd. (United Kingdom) 
5 New Investigator

Nathaniel J. Pope, Tri Service Research Laboratory (United States)

6 PBM Clinical Translation

Praveen Arany, University at Buffalo (United States) 